\title{
A Selective High Performance Liquid Chromatographic Method to Follow the Hydrolytic Degradation of Nicardipine Hydrochloride
}

\author{
K. E. IBRAHIM*, R. M. AL-ASHBAN ${ }^{\S}$ and L. B. BABIKER ${ }^{\S}$ \\ Department of Pharmaceutical Chemistry, \\ Faculty of Pharmacy, University of Khartoum, Sudan, \\ ${ }^{\S}$ Central Laboratory for Food and Drug Analysis, Saudi Arabia. \\ kamalibrahime@yahoo.com
}

Received 12 May 2009; Accepted 10 July 2009

\begin{abstract}
A simple, stability indicating, reverse phase high performance liquid chromatographic method was developed and validated for determination of nicardipine hydrochloride (NC) in the presence of its degradation products. The chromatographic separation was performed on Hypersil, BDS-C18, $30 \mathrm{~cm} \times 3.9$ $\mathrm{mm}$ id, at ambient temperature with UV-detection at $254 \mathrm{~nm}$. A mixture of $20 \%$ $(\mathrm{v} / \mathrm{v})$ aqueous $0.01 \mathrm{M}$ sodium acetate/acetic acid buffer $(\mathrm{pH} 4.5)$ and $80 \%$ acetonitrile was used as the mobile phase at a flow rate of $1.5 \mathrm{~mL} \mathrm{~min}^{-1}$, losartan was used as internal standard. The calibration curve is linear over the concentration range 5-40 $\mu \mathrm{g} \mathrm{mL}^{-1}$, with a regression coefficient of 0.9984 and the $\%$ recovery was $99.78 \pm 0.17$. The method was used to investigate the kinetics of alkaline, acids induced degradation, effect of buffer concentration and temperature. The degradation followed first-order kinetics. The rate constant, half-life time, and activation energy were calculated
\end{abstract}

Keywords: Nicardipine hydrochloride, HPLC, Hydrolytic Degradation.

\section{Introduction}

Nicardipine hydrochloride (Figure 1) is chemically known as 2-(benzyl (methyl) amino) ethyl methyl 1, 4-dihydro-2, 6-dimethyl-4-(3-nitrophenyl) pyridine-3, 5-dicarboxylate hydrochloride $^{1}$. It is a calcium antagonist of the dihydropyridine class and has been widely used for the treatment of hypertension and angina pectoris ${ }^{2}$.

Several methods have been reported for determination of nicardipine hydrochloride. These include spectrophotometry ${ }^{3-5}$, voltammetry ${ }^{6-8}$, high performance liquid chromatography ${ }^{9-12}$, liquid chromatography mass spectroscopy ${ }^{13-15}$ and capillary electrophoresis ${ }^{16}$. Most of these methods were used for quantitative determination of nicardipine hydrochloride in biological fluids. 
Drug degradation is a serious problem which renders the job of quality control analyst very critical and is usually associated with stability of the drug. Investigations on stability during a laboratory process are necessary to establish the precautions required during development and control of dosage form as well as for development and validation of quantitative methods. Generally stability of drugs or pharmaceutical preparations depends on temperature, concentration, $\mathrm{pH}$, oxygen content, light intensity, wave length and other factors. Reviewing the literature, revealed that, only the effect of light on nicardipine $\mathrm{HCl}$ has been studied.

The aim of the present work was to develop, validate and apply a stability indicating HPLC method for determination nicardipine $\mathrm{HCl}$ and its alkaline and acid hydrolytics products. The developed method was used to investigate the kinetics of the drug degradation in different media at different temperatures.<smiles>CC(=O)C1=C(C)NC(C)=C(C(=O)OCCN(C)Cc2ccccc2)C1c1cccc([N+](=O)[O-])c1</smiles>

Figure 1. Structural formula of nicardipine hydrochloride.

\section{Experimental}

The pure sample of nicardipine hydrochloride was purchased from Sigma (St. Louis, Mo, USA). The commercial capsules (Pelcard $50 \mathrm{mg}$ Batch \# 65801) were obtained from commercial sources. Methanol, acetonitrile, (all of HPLC grades), hydrochloric acid (Analar), monobasic sodium phosphate, ammonium acetate, boric acid, sodium acetate and glacial acetic acid (Analar) were obtained from BDH (Poole, UK). Phosphoric acid, ethanol, and potassium hydroxide were obtained from E; Merck (Darmstadt, Germany).Losartan was purchased from Sigma (St. Louis,Mo,USA).

\section{Apparatus}

Seperation was performed on Shimadzu class-vp v6.LC-2010A liquid chromatography, equipped with UVB50 varian detecter, rheodyne injector and the wavelength used was 254 nm.

\section{Column and mobile phase}

Separation was achieved on Hypersil, BDS- C18, $(5 \mu \mathrm{m}), 30 \mathrm{~cm} \times 3.9 \mathrm{~mm}$ id. The mobile phase consists of $20 \%(\mathrm{v} / \mathrm{v})$ aqueous $0.01 \mathrm{M}$ sodium acetate/acetic acid ( $\mathrm{pH} 4.5)$ and $80 \%$ (v/v) acetonitrile.

\section{Standard solution}

A stock solution of $0.04 \%(\mathrm{w} / \mathrm{v})$ of nicardipine $\mathrm{HCl}$ reference material in the mobile phase was prepared and working solutions were prepared by appropriate dilutions.

\section{Internal standard}

A stock solution of $0.01 \%(\mathrm{w} / \mathrm{v})$ of losartan was prepared in the mobile phase and working solutions were prepared accordingly. 


\section{preparation of solutions of alkalis and acid degradation}

For the effect of alkalis and acids on nicardipine $\mathrm{HCl}$, solutions of the drug with a concentration of $40 \mu \mathrm{g} / \mathrm{mL}$ were treated with solutions of either sodium hydroxide of different molar concentrations $(0.1 \mathrm{M}, 0.2 \mathrm{M}, 0.3 \mathrm{M}, 0.4 \mathrm{M}, 0.5 \mathrm{M}$ and $1.0 \mathrm{M})$ of $\mathrm{HCl}$. The experiments were conducted at room temperature. The solutions were then neutralized with $0.1 \mathrm{M}, 0.2 \mathrm{M}, 0.3 \mathrm{M}, 0.4 \mathrm{M}$, and $0.5 \mathrm{M} \mathrm{HCl}$ and $1.0 \mathrm{M} \mathrm{NaOH}$ and diluted to volume with mobile phase.

\section{Calibration curve}

Aliquots of the standard solution covering the working range $(5,10,15,20,25,30,35$ and $40 \mu \mathrm{g} / \mathrm{mL}^{-1}$ ) of nicardipine were prepared in mobile phase with $20 \mu \mathrm{gmL}^{-1}$ of the internal standard. Ten microliter aliquots were injected (in triplicate) and eluted with the mobile phase under the reported chromatographic conditions. The calibration curve was constructed by plotting the peak area ratio of nicardipine $\mathrm{HCl}$ to that of losartan (internal standard) versus concentration. The linear regression equation was derived.

\section{Study of the factors affecting the degradation kinetics of nicardipine $\mathrm{HCl}$}

Asolution of nicardipine $\mathrm{HCl}\left(40 \mu \mathrm{gmL}^{-1)}\right.$ was used to study the effect of temperature and $\mathrm{pH}$. The solutions were treated with different concentrations of $\mathrm{NaOH}(0.1 \mathrm{M}, 0.2 \mathrm{M}, 0.3 \mathrm{M}$, $0.4 \mathrm{M}$ and $0.5 \mathrm{M})$ and kept at different temperatures $\left(70-100{ }^{\circ} \mathrm{C}\right)$. The solutions were then neuterlized with $0.1 \mathrm{M}, 0.2 \mathrm{M}, 0.3 \mathrm{M}, 0.4 \mathrm{M}$ and $0.5 \mathrm{M} \mathrm{HCl}$ and diluted with mobile phase. For the effect of $\mathrm{pH}$ four buffer systems (citrate, phosphate, borate and acetate) of different $\mathrm{pH}$ were used with the same concentration of nicardipine $\mathrm{HCl}\left(40 \mu \mathrm{gmL}^{-1}\right)$.

\section{Analysis of capsules}

A solution of nicardipine $\mathrm{HCl}$ was prepared and injected using the prescribed method and the nominal content of the capsule $\mathrm{s}$ were calculated using the calibration graph.

\section{Results and Discussion}

\section{Chromatographic separation}

Figure 2 is a chromatogram obtained from standard solution of nicardipine and its degradation products (I and II), resulting from alkaline degradation under the prescribed chromatographic conditions. The method allows complete base line separation with a good resolution factor (6.5) between each two adjacent peaks. The proposed method was assessed for specificity, linearity, precision and recovery (Table 1).

\section{Degradation kinetics study}

\section{Effect of acids}

The result was obtained by treating a solution of $40 \mu \mathrm{g} / \mathrm{mL}$ with $1.0 \mathrm{M} \mathrm{HCl}$. The kinetics parameters for degradation of nicardipine $\mathrm{HCl}$ in acid medium were found to be first order. The plotting of $\log (\mathrm{a} / \mathrm{a}-\mathrm{x})$ against time $(\mathrm{t})$ was found to be straight line. The rate constant $(\mathrm{k})$ and the half-life time $\left(\mathrm{t}_{1 / 2}\right)$ were found to be $1.38 \times 10^{-3} \mathrm{~min}^{-1}$ and $502 \mathrm{~min}$. respectively.

\section{Effect of alkalis}

The effect of alkalis on the degradation of nicardipine $\mathrm{HCl}$ was studied by using increasing concentrations of sodium hydroxide: $0.1 \mathrm{M}, 0.2 \mathrm{M}, 0.30 .4 \mathrm{M}$ and $0.5 \mathrm{M}$ at room and elevated temperatures. At room temperature, increasing the concentration of sodium hydroxide resulted in increasing the rate of degradation and the value of the reaction rate constant $(\mathrm{k})$ and decreasing in the half-life $(\mathrm{t} 1 / 2)$ (Table 2$)$. 


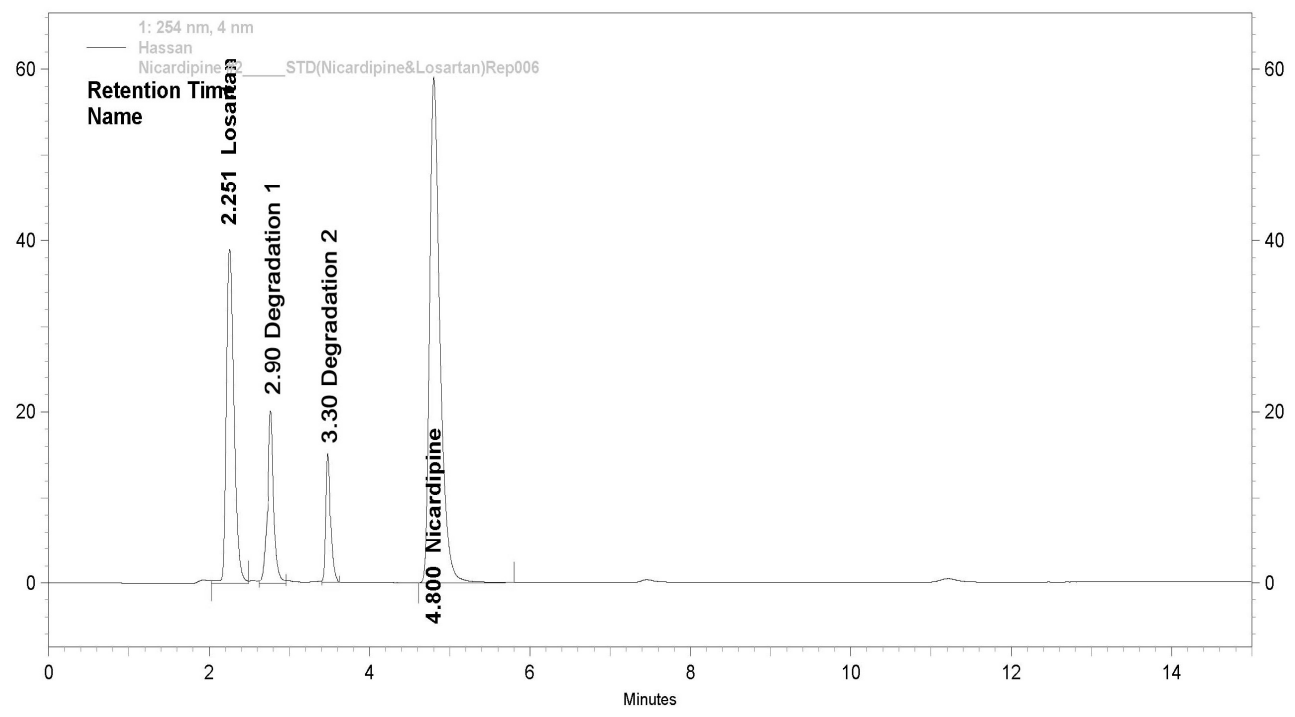

Figure 2. Chromatogram of nicardipine $\mathrm{HCl}$ and its degradation products.

Table 1. Analytical parameters for the HPLC method of determination of nicardipine adopting the proposed method.

\begin{tabular}{ll}
\hline Parameter & Standard nicardipine \\
\hline Concentration range, $\mu \mathrm{g} / \mathrm{mL}$ & $5-40$ \\
Correlation coefficient $(\mathrm{r})$ & 0.9984 \\
Slope & 0.121 \\
Intercept & 0.0146 \\
$\mathrm{RSD} \%$ & 0.17 \\
$\% \mathrm{ER}$ & 0.064 \\
$\% \mathrm{R}$ & $99.78+0.17$ \\
\hline
\end{tabular}

Table 2. Effect of concentration of sodium hydroxide on the kinetic parameters of nicardipine $\mathrm{HCl}(40 \mu \mathrm{g} / \mathrm{mL})$ at room temperature.

\begin{tabular}{ccc}
\hline Conc. of $\mathrm{NaOH}, \mathrm{M}$ & $\mathrm{K} 10^{3}, \mathrm{~min}^{-1}$ & $\mathrm{t}_{1 / 2}, \min$ \\
\hline 0.1 & 1.15 & 601 \\
0.2 & 1.84 & 376 \\
0.3 & 2.30 & 300 \\
0.4 & 2.76 & 250 \\
0.5 & 3.68 & 188 \\
\hline
\end{tabular}

Result of the effect of alkaline degradation at different temperatures $\left(70-100{ }^{0} \mathrm{C}\right)$ are shown in Table 3 . The values of the reaction rate constant $\left(\mathrm{k}, \mathrm{min}^{-1}\right)$, half-life times $\left(\mathrm{t}_{1 / 2}\right.$ min) and activation energy $\left(\mathrm{Ea}, \mathrm{kcal}_{\mathrm{mol}}{ }^{-1}\right)$ are listed. Plotting $\log \mathrm{K}_{\mathrm{obs}}$ values $v s \mathrm{1} / \mathrm{T}$, the Arrhenius plot was obtained (Figure 3). From these data, the rate of degradation of nicardipine was found to increase upon increasing both temperature and concentration of sodium hydroxide. 


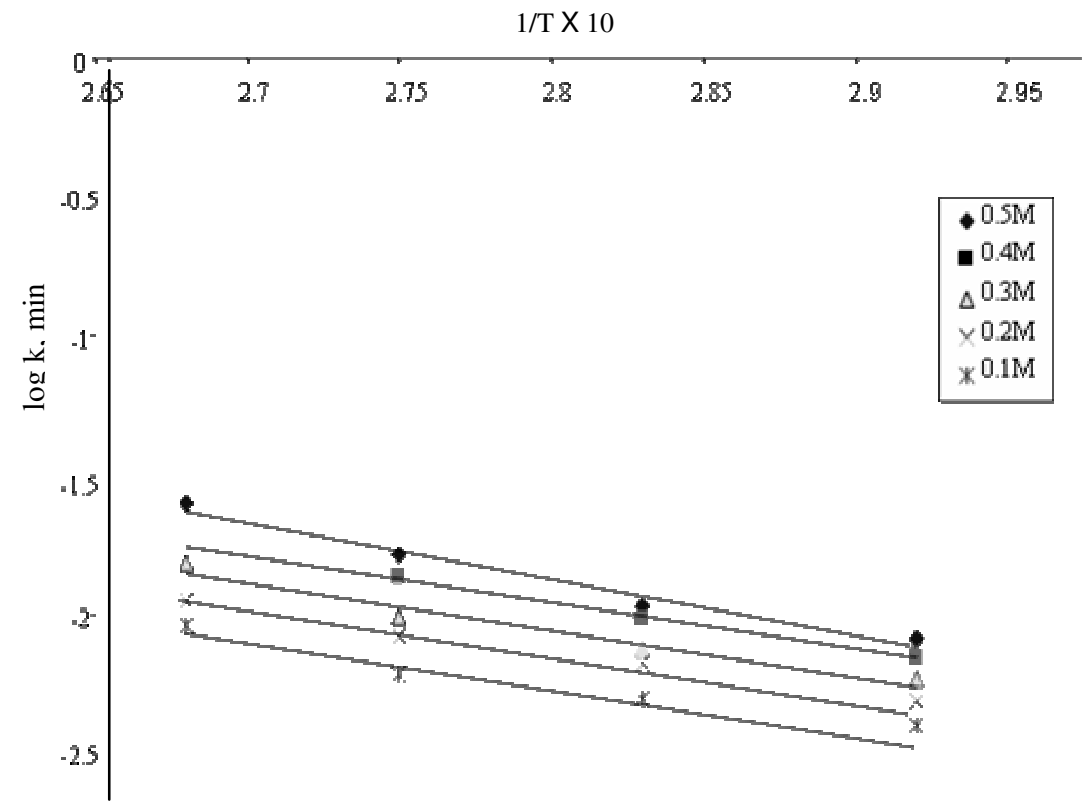

Figure 3. Arrhenius plots for nicardipine $\mathrm{HCl}$ at different concentrations of $\mathrm{NaOH}$.

Table 3. Effect of temperature on the kinetic parameters of nicardipine $\mathrm{HCl}(40 \mu \mathrm{g} / \mathrm{mL})$ at different concentrations of sodium hydroxide.

\begin{tabular}{|c|c|c|c|c|}
\hline Conc. of $\mathrm{NaOH}, \mathrm{M}$ & Temperature, ${ }^{0} \mathrm{C}$ & $\mathrm{K}, \mathrm{min}^{-1}$ & $\mathrm{t} 1 / 2 \min$ & Ea' kcal.mol $^{-1}$ \\
\hline \multirow{4}{*}{$0.1 \mathrm{M}$} & 70 & $3.91 \times 10^{-3}$ & 177 & \multirow{4}{*}{$X=7.13$} \\
\hline & 80 & $4.83 \times 10^{-3}$ & 143 & \\
\hline & 90 & $5.98 \times 10^{-3}$ & 115 & \\
\hline & 100 & $8.98 \times 10^{-3}$ & 77 & \\
\hline \multirow{4}{*}{$0.2 \mathrm{M}$} & 70 & $4.83 \times 10^{-3}$ & 143 & \multirow{4}{*}{$X=7.20$} \\
\hline & 80 & $6.67 \times 10^{-3}$ & 103 & \\
\hline & 90 & $8.29 \times 10^{-3}$ & 83 & \\
\hline & 100 & 0.01128 & 61 & \\
\hline \multirow{4}{*}{$0.3 \mathrm{M}$} & 70 & $5.75 \times 10^{-3}$ & 120 & \multirow{4}{*}{$X=8.16$} \\
\hline & 80 & $7.36 \times 10^{-3}$ & 94 & \\
\hline & 90 & $9.69 \times 10^{-3}$ & 71 & \\
\hline & 100 & 0.01496 & 46 & \\
\hline \multirow{4}{*}{$0.4 \mathrm{M}$} & 70 & $7.13 \times 10^{-3}$ & 97 & \multirow{4}{*}{$X=8.0$} \\
\hline & 80 & $9.44 \times 10^{-3}$ & 74 & \\
\hline & 90 & 0.01335 & 52 & \\
\hline & 100 & 0.01893 & 38 & \\
\hline \multirow{4}{*}{$0.5 \mathrm{M}$} & 70 & $7.83 \times 10^{-3}$ & 88 & \multirow{4}{*}{$X=9.97$} \\
\hline & 80 & 0.01036 & 67 & \\
\hline & 90 & 0.0161 & 43 & \\
\hline & 100 & 0.0251 & 28 & \\
\hline
\end{tabular}




\section{Effect of buffer}

The result of the effect of type and concentration of buffers on the reaction rate constant at room temperature are shown in Table 4. Based on the effect of different buffers with different $\mathrm{pH}$ values on the rate of degradation of nicardipine $\mathrm{HCl}$ at $100{ }^{0} \mathrm{C}$ (Table 5), the following conclusions are drawn:

- For the same type of buffer: increasing the $\mathrm{pH}$ increases the rate of degradation.

- Citrate buffers increase the rate of degradation more than phosphate more than borate and finally acetate.

Table 4. The calculated pseudo-first order rate constant $\left(\mathrm{k}_{\mathrm{obs}}\right)$ and half-lives of degradation of nicardipine $\mathrm{HCl}$ at various $\mathrm{pH}$ values at room temperature $\left(\right.$ at $22{ }^{\circ} \mathrm{C}$ ).

\begin{tabular}{ccccc}
\hline $\mathrm{pH}$ & Buffer composition & $\mathrm{K}_{\mathrm{obs}}$ day $^{-1}$ & Half life $\mathrm{t}_{1 / 2}$ (day) & $\log _{\mathrm{o}}$ \\
\hline 1.1 & $\mathrm{HCl}$ & $4 \times 10^{-2}$ & 17.30 & -1.40 \\
2.45 & Acetate & $1.92 \times 10^{-3}$ & 155.00 & -2.71 \\
3.40 & Citrate & $1.5 \times 10^{-3}$ & 462.00 & -2.82 \\
4.50 & Citrate & $8.91 \times 10^{-4}$ & 777.00 & -3.05 \\
5.20 & Citrate & $1.41 \times 10^{-3}$ & 491.00 & -2.85 \\
6.00 & Citrate & $0.564 \times 10^{-1}$ & 8.62 & -0.23 \\
7.00 & Phosphate & $27.7 \times 10^{-1}$ & 17.50 & -0.56 \\
8.30 & Borate & $0.1 \times 10^{-1}$ & 6.93 & -1 \\
9.00 & Borate & $0.316 \times 10^{-1}$ & 2.19 & -0.50 \\
10.00 & Borate & 1.58 & 0.46 & 0.19 \\
11.20 & NaOH & 6.58 & 0.21 & 0.81 \\
13.00 & NaOH & $1.09 \times 10^{-3}$ & 0.44 & -2.96 \\
\hline
\end{tabular}

Table 5. Comparison between the different buffer systems on the degradation of nicardipine $(40 \mu \mathrm{g} / \mathrm{mL})$ at $100{ }^{\circ} \mathrm{C}$.

\begin{tabular}{lccc}
\hline \multicolumn{1}{c}{ Type of Buffer } & $\mathrm{k}, \mathrm{min}^{-1}$ & $\log \mathrm{k}$ & $\mathrm{t}_{1 / 2}, \min$ \\
\hline Citrate buffer pH 6 & 0.0154 & -1.81 & 44.91 \\
Citrate buffer pH 5.2 & 0.0108 & -1.96 & 64.00 \\
Citrate buffer pH 4.5 & 0.0069 & -2.11 & 100.00 \\
Phosphate buffer pH 9 & 0.0159 & -1.79 & 43.61 \\
Phosphate buffer pH 8 & 0.013 & -1.88 & 52.79 \\
Phosphate buffer pH 7.5 & 0.011 & -1.95 & 61.41 \\
Phosphate buffer pH 6.5 & 0.0092 & -2.04 & 75.22 \\
Borate buffer pH 10 & 0.014 & -1.85 & 49.33 \\
Borate buffer pH 9 & 0.011 & -1.96 & 62.69 \\
Borate buffer pH 8 & 0.0089 & -2.04 & 77.16 \\
Acetate buffer pH 5 & 0.0076 & -2.12 & 91.00 \\
Acetate buffer pH 4.5 & 0.0041 & -9.38 & 1.67 \\
\hline
\end{tabular}

Application of the proposed method to analysis of nicardipine in its commercial capsules

The proposed method was applied to determination of nicardipine in its commercial capsules. The percentage recoveries were obtained Table 6 . 
Table 6. Application of the proposed HPLC method to the determination of nicardipine in commercial capsules

\begin{tabular}{llll}
\hline \multicolumn{1}{c}{ Compound } & $\begin{array}{c}\text { Concentration } \\
\text { taken, } \mu \mathrm{g} / \mathrm{mL}^{-1}\end{array}$ & $\begin{array}{l}\text { Concentration } \\
\text { found, } \mu \mathrm{g} / \mathrm{mL}^{-1}\end{array}$ & Recovery, \% \\
\hline Pelcard 50 mg & 20 & 20.04 & 100.20 \\
capsule & 30 & 30.558 & 101.86 \\
NC HCl (50 mg/capsule) & 40 & 40.316 & 100.79 \\
& & Mean \pm S.D $=100.95 \pm 0.841$ \\
\hline
\end{tabular}

\section{Pathway of degradation}

Treatment of nicardipine with sodium hydroxide at elevated temperature resulted in cleavage of the ester linkage and the production of two compounds, I (acid) and II (alcohol) as shown blow:<smiles>COC(=O)C1=C(C)NC(C)=C(C(=O)OCCN(C)Cc2ccccc2)C1c1cccc([N+](=O)[O-])c1</smiles><smiles>COC(=O)C1=C(C)NC(C)=C(C(=O)OC)C1c1cccc([N+](=O)[O-])c1</smiles>

I

II

Compound I is eluted first, as it is more polar than either compound II or nicardipine. It is possible that, the ester group in the side chain at position 5 is also hydrolysed. However, this will not have a pronounced effect the chromatogram developed. Study of kinetic parameters for the degradation of nicardipine involved measuring the peak heights of nicardipine and internal standard only.

\section{Conclusion}

A rapid, precise, and specific HPLC method using a single isocratic system has been developed for the determination of nicardipine $\mathrm{HCl}$, either alone or in the presence of its degradation products. The method was used to determine the degradation kinetics parameters of nicardipine and the drug was found to be most stable at $\mathrm{pH}=4.5$.

The energy of activation calculated from Arrhenius plot suggests that a typical hydrolytic reaction is involved. The rate of the decomposition increases considerably in the alkaline medium. This agrees with the fact that ester linkages are more susceptible to cleavage in alkaline medium than in acid medium. 
The catalytic effect of four buffers, namely, phosphate, borate, citrate and acetate buffer indicated that the citrate exerts a more catalytic activity than the other three buffers of which acetate apparently has no effect on the rate of degradation of nicadipine hydrochloride.

\section{References}

1. Budavari S, in the Merck index, $13^{\text {th }}$ Ed., Merck \& Co Inc., 2001.

2. Sorkin E M and Clissold S P, Drugs, 1987, 33, 296.

3. Escrig-Tena I, Rodriguez L A, Esteve-Romero J and Garcia Alvarez M C, Talanta, 1998, 47, 43-52.

4. Rango G, Vetuschi C, Risoli A and Ioele G, Talanta, 2003, 59, 375-382.

5. Marciniec B and Ogrodowczyk M, Acta Pol Pharma., 2006, 63, 477-484.

6. Obendorf D and Stubauer G, J Pharm Biomed Anal., 1995, 13, 1339-1341.

7. Ozkan S A, Uslu B and Aboul- Enein H Y, Crit Rev Anal Chem., 2003, 33, 155-181.

8. Atkosar Z, Altiokka G and Tuncel M, Pharmazie, 1997, 52, 959- 960.

9. Uno T, Ohkubot T and Sugawara K, J Chromatogr B; Biomed Sci Appl., 1997, 698, 181-186.

10. Lopez J A, Martinez V, Alonso R M and Jimenez R M, J Chromatogr A, 2000, 870, 105-114.

11. Fernandez C M and Veiga F J B, Biomed Chromatogr, 2003, 17, 33-38.

12. Ke Li, Xin Zhang, Yi-sheng Yuan and Fei-lang Zhao, Biomed Chromatogr, 1998, 12, 326-329.

13. Meiling Q, Wang P and Jin X, J Chromatogr B, 2006, 830, 81-85.

14. Bakhtiar R and Tse F L, Rapid Commun.Mass Spectrom., 2000, 14, 1128-1135.

15. Chen Sh-M, Hsieh M-C, Chao Su-Hui, Chang E E, Wang Po-Yu and An-Bang Wu, Biomed Chromatogr, 2008, 22,1008-1012.

16. Pomponio R, Gotti R, Fiori J, Cavrini V, Mura P, Crri M and Maestrelli F, Biomed Anal., 2004, 35, 267-275. 


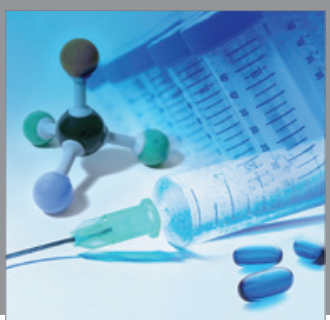

International Journal of

Medicinal Chemistry

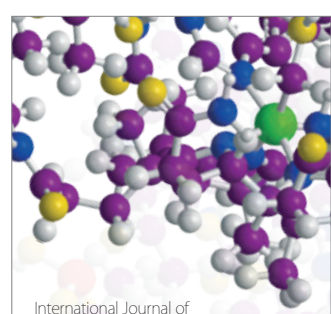

Carbohydrate Chemistry

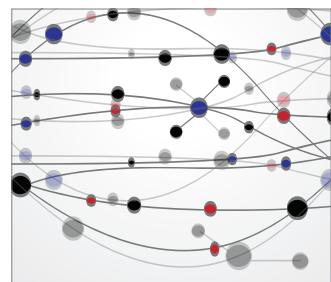

The Scientific World Journal
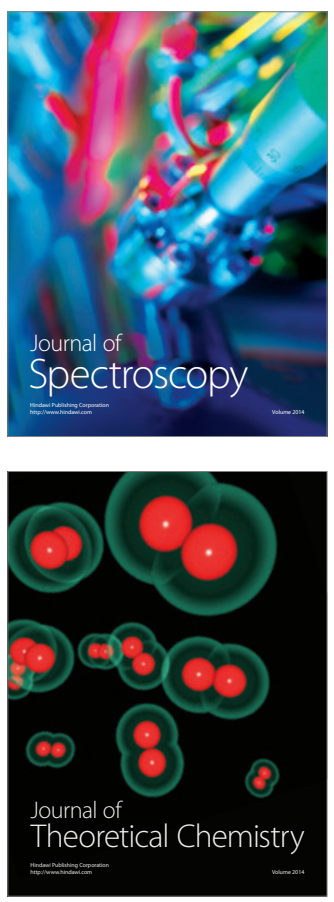
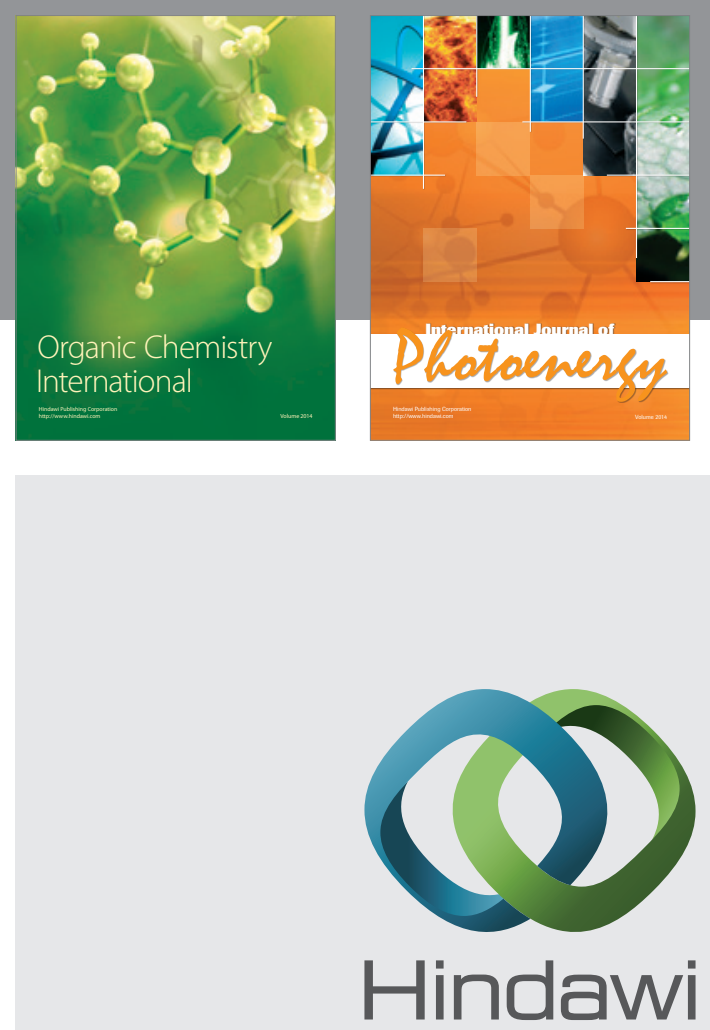

Submit your manuscripts at

http://www.hindawi.com
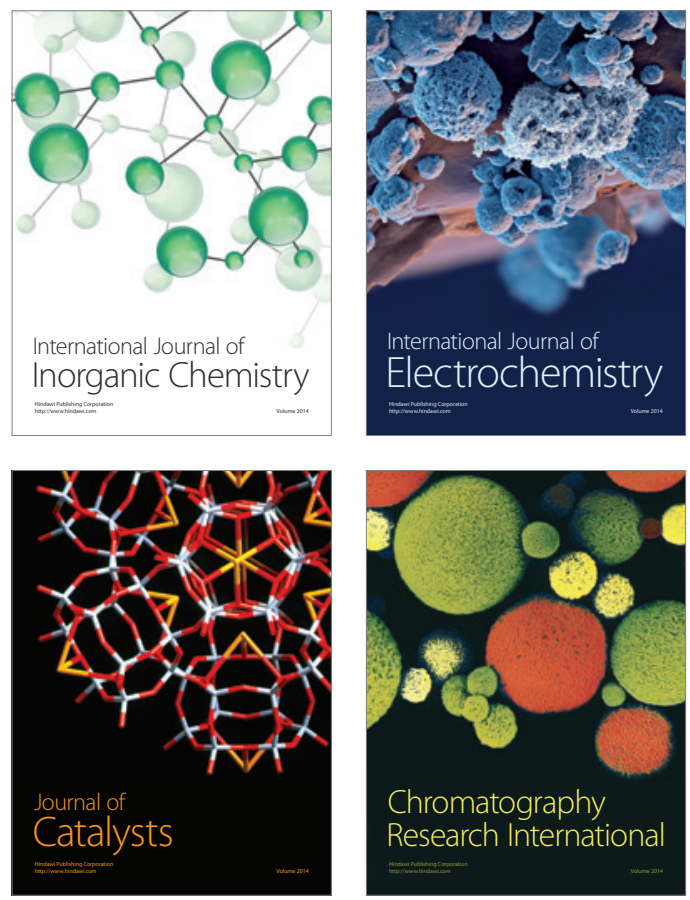
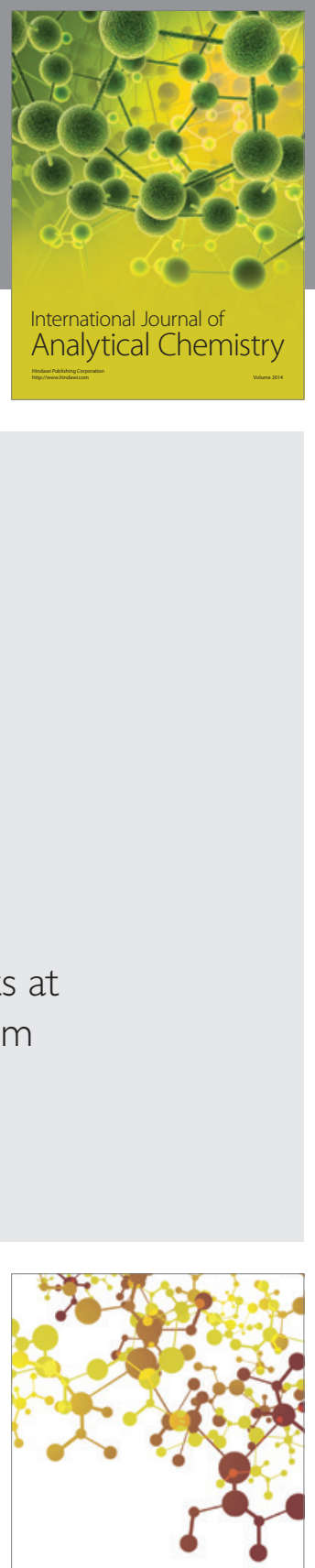

Journal of

Applied Chemistry
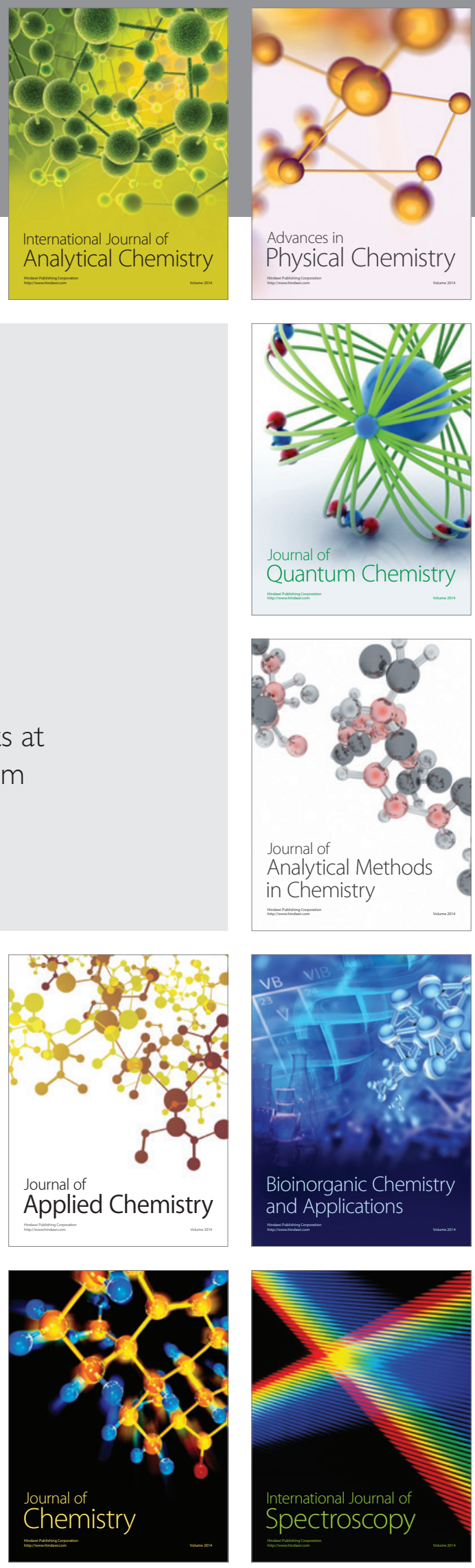